\begin{tabular}{|c|l|}
\hline Title & Photosynthetic nitrogen and water use efficiency of acacia and eucaly pt seedlings as afforestation species \\
\hline Author(s) & Novriyanti, E.; Watanabe, M.; Makoto, K.; Takeda, T.; Hashidoko, Y.; Koike, T. \\
\hline Citation & $\begin{array}{l}\text { Photosynthetica, 50(2), 273-281 } \\
\text { https://doi.org/10.1007/311099-012-0033-7 }\end{array}$ \\
\hline Issue Date & $2012-06$ \\
\hline Doc URL & http://hdl.handle.net/2115/49557 \\
\hline Rights & The final publication is available at www.springerlink.com \\
\hline Type & article (author version) \\
\hline File Information & Pho50-2_273-281.pdf \\
\hline
\end{tabular}

Instructions for use 


\title{
Photosynthetic nitrogen and water use efficiency of acacia and eucalypt seedlings as afforestation species
}

\author{
E. NOVRIYANTI*, M. WATANABE ${ }^{* *}$, K. MAKOTO $^{* * *}$, T. TAKEDA ${ }^{\#}$, Y. HASHIDOKO $^{* *}$, \\ T. KOIKE ${ }^{* *},+$ \\ Graduate School of Agriculture, Hokkaido University, Sapporo-060-8589 Japan ${ }^{*}$ \\ Research Faculty of Agriculture, Hokkaido University, Sapporo-060-8580 Japan ${ }^{* *}$ \\ The Climate Impact Research Center, Umeå University, Abisko-981 07, Sweden*** \\ Oji Paper Co. Ltd., Tomakomai, Japan ${ }^{\#}$ \\ Corresponding author (tkoike@for.agr.hokudai.ac.jp) ${ }^{+}$
}

\begin{abstract}
The ecophysiological traits of acacia and eucalypt are important in assessing their suitability for afforestation. We measured the gas-exchange rate, the leaf dry mass per area (LMA) and the leaf nitrogen content of two acacia and four eucalypt species. Relative to the eucalypts, the acacias had lower leaf net photosynthetic rate $\left(P_{\mathrm{N}}\right)$, lower photosynthetic nitrogen-use efficiency (PNUE), higher water-use efficiency (WUE), higher LMA and higher leaf nitrogen per unit area $\left(N_{\text {area }}\right)$. No clear differences were observed within or between genera in the maximum rate of carboxylation $\left(V_{\mathrm{cmax}}\right)$ or the maximum rate of electron transport $\left(J_{\max }\right)$, although these parameters tended to be higher in eucalypts. PNUE and LMA were negatively correlated. We conclude that acacias with higher LMA do not allocate nitrogen efficiently to photosynthetic system, explaining why their $P_{\mathrm{N}}$ and PNUE were lower than in eucalypts.
\end{abstract}

Additional keywords: Afforestation; fast growing species; photosynthetic nitrogen-use efficiency; photosynthetic water-use efficiency.

Abbreviations: $C_{\mathrm{i}}-$ leaf intercellular $\mathrm{CO}_{2}$ concentration; $E$ - leaf transpiration rate; $g_{\mathrm{s}}-$ stomatal conductance; $J_{\max }$ - maximum rate of electron transport; LMA - leaf dry mass per area; $N_{\text {area }}$ - leaf nitrogen per area; $N_{\text {mass }}$ - leaf nitrogen per dry mass; $P_{\mathrm{N}}-$ leaf net 
photosynthetic rate; $P_{\mathrm{Nmax}}$ - light-saturated net photosynthetic rate; PNUE - photosynthetic nitrogen-use efficiency; $V_{\mathrm{c}, \max }-$ maximum rate of carboxylation; VPD - vapour pressure deficit; WUE - photosynthetic water-use efficiency.

Acknowledgement: We grateful for financial support provided in part by a grant-in-aid from JSPS (innovation research: 21114008, Type B: 23380078) to T.K, and Research Fellowships for Young Scientist (20.1143) to M.W. We thank Dr. Anthony Garrett of Scitext Cambridge for guidance in improving our English. We appreciate the Reviewers for the constructive comments.

\section{Introduction}

Nitrogen $(\mathrm{N})$ and water are essential for the photosynthetic and plant growth and survival. The efficiency with which these resources are used in the assimilation process is expressed by means of the photosynthetic nitrogen use efficiency (PNUE) and the photosynthetic water use efficiency (WUE). The PNUE and WUE are capable of predicting how the net photosynthetic capacity is optimized per unit of water and $\mathrm{N}$ in leaves (e.g. Castellanos et al. 2005). The PNUE is an important parameter in determining the efficiency of $\mathrm{N}$ utilization for growth (Garnier et al. 1995, Poorter and Evans 1998, Larcher 2003) so that it is a useful indicator of plant performance in relation to edaphic condition (Funk and Vitousek 2007, Huang et al. 2008). PNUE is a key characteristic of leaves of differing species, and is related to leaf economics, leaf physiology, strategy (e.g. Wright et al. 2004a), and competition (Robinson et al. 2001). Species with a high PNUE tend to have high growth rates (e.g. Reich et al. 1995, Hikosaka 2004). Poorter and Evans (1998) stated that variation in PNUE is linked with a suite of traits that determined the growth potential of a species. 
The photosynthetic water use efficiency (WUE) is related to the optimum water use of plants (Robinson et al. 2001, Larcher 2003). The WUE underpins plant responses to the competition for water under xeric conditions (e.g. Schulze et al. 2005). In forest ecosystems, WUE is a critical link between wood production and forest water management (e.g. Cernusak et al. 2007).

Regardless of strong correlation between leaves $\mathrm{N}$ and photosynthetic rate; the ratio of photosynthesis rate to leaf $\mathrm{N}$ (PNUE) is often found to be variable. LMA is the inverse of specific leaf area (SLA) and as there is a strong correlation between PNUE and specific leaf area (SLA) (Poorter and Evans 1998, Schulze 2005), thus LMA can be used to describe the variation on PNUE (Poorter and Evans 1998). LMA interconnects with a suite of traits that are important determinant of variation in plants growth rate (e.g. Poorter and Evans 1998). Then, at the measured-LMA, a variation in PNUE may capable in explaining the difference in photosynthetic rate between species that divergent inherently (Reich et al. 1995), such as in acacia and eucalypt.

Acacia and eucalypt are both fast growing plants, yet differ inherently e.g. in leaf morphology and chemistry. Eucalypts bear true-leaves, whereas some acacias are characterized by phyllodes. The anatomical structure of the phyllodes and true leaves are very different (e.g. Leroy et al. 2009). Differences in leaf traits between acacias and eucalypts should influence their physiological function, including their photosynthetic activity.

Leaf morphological traits, e.g. leaf mass per unit area (LMA) (e.g. Niinemets 1999a, Lee et al. 2000) and chemical composition (i.e. leaf nitrogen content) are reportedly to be positively correlated with the photosynthetic capacity per unit leaf area. This shall assist in seedling selection for afforestation, taking into account the photosynthetic efficiency of the seedlings. This in turn depends on structural and biochemical parameters, and influences the plant growth (Barja et al. 2001, Alves et al. 2002, Kruger and Volin 2006). 
Acacias and eucalypts are pioneer species suitable for afforestation (e.g. Jøker 2000, Alves et al. 2002, Takahashi et al. 2002, Orwa et al. 2009). In particular, acacias through symbiotic nitrogen-fixing could improve the soil nitrogen (N) condition (Yang et al. 2009). Acacias (Armstrong 1998, Francis 2002, Forrester et al. 2006, Hai 2009) and eucalypts (Grattapaglia and Sederoff 1994) have been planted widely around the world because of their rapid growth traits and adaptability to diverse growth conditions.

Both acacia and eucalypts are known to have high photosynthetic rate, which is responsible for their high growth rate. Growth (e.g. Pinyopusarerk et al. 1996, Heriansyah et al. 2007, Hai 2009, Quang et al. 2010) and photosynthetic traits (e.g. Yu and Ong 2003, Grassi et al. 2002, Lewis et al. 2011) of species in both genera had been well described. Some studies had elucidated the relation of photosynthetic rate with leaf $\mathrm{N}$ and/or LMA of eucalypts and acacia (e.g. Prior et al. 2004, Harrison et al. 2009). However, little information is available to facilitate comparison of PNUE and WUE at the measured-LMA.

The two genera tend to grow in different natural environments (Tunstall 2005), and to maintain their growth and productivity they are believed to employ different strategies, as reflected in the PNUE and WUE. Species with high LMA almost invariably have low PNUE as a result of the higher $N_{\text {mass }}$ (e.g. Poorter and Evans 1998). We therefore believe that acacias with nitrogen-fixing capacity would have greater leaf $N_{\text {mass }}$ and $N_{\text {area }}$ and higher LMA, and hence lower PNUE, than eucalypts. In this study we analyzed the variation of PNUE and photosynthetic WUE of two acacias and four eucalypts which have different LMA, so as to clarify the photosynthetic traits for assessing their suitability for afforestation. 


\section{Materials and Methods}

Plant materials and growth conditions: We studied two acacia and four eucalypt species: Acacia auriculiformis, A. mangium, Eucalyptus camaldulensis, E. urophylla, E. grandis, and E. globulus. These are among the most popular species used for man-made forests. The seeds were obtained from Australia Tree Seed Centre of CSIRO, Kingston, Australia. They were germinated in March 2008 and subsequently grown in a glasshouse equipped with vitreous silica (through which shorter wavelengths of light can pass) in the Agriculture School of Hokkaido University, Sapporo, Japan $\left(43^{\circ} 0^{\prime} \mathrm{N}, 141^{\circ} 2^{\prime} \mathrm{E}\right)$. The seedlings were grown under identical conditions with a supply of nutrient, $100 \mathrm{ml}$ of 500-fold diluted Hyponex $(\mathrm{N}: \mathrm{P}: \mathrm{K}=$ 6:10:5, Hyponex Corp. JAPAN, Osaka, Japan) which was applied to each plant once a week. The daily temperature and relative humidity $(\mathrm{RH})$ in the glasshouse were maintained at $25 \pm 2^{\circ} \mathrm{C}$ and $70 \%$. The growing medium was a mixture of Kanuma pumice soil and clay soil (1:1) in the standard 7 liter pot commonly used in nursery practices. Pots were watered daily so as to sustain the soil moisture. The measurements comprised three replications for each species.

Typical natural environment of the tested species: Acacia auriculiformis and A. mangium are found naturally in Australia, Papua New Guinea, and Indonesia (e.g. Bino 1998). Although they grow better in areas with high rainfall, their natural habitat ranges from tropical dry to moist, and subtropical dry to wet, forest zone. They tolerate a wide range of soil types, from fertile to eroded soil, and prefer warm humid condition (e.g. Turnbull 1986).

Three of our eucalypts species are indigenous to Australia, and E. urophylla originates from Indonesia (Baltazar et al. 2009). All four species have been used for afforestation (Hengari 2007). Although their growth is enhanced in the warm region, they tolerate colder 
environment better than the acacias, thus can survive the harsh subtropics environment. $E$. grandis (Schonau 1984) and E. urophylla (Baltazar et al. 2009), however, are sensitive to frost, whereas E. gobulus can tolerate temperature as low as $-8^{\circ} \mathrm{C}$ (Goudzwaard 2011). These eucalypts can grow on a wide range of soil types with varied fertility. They can be found in areas with mean-annual rainfall ranging from $250 \mathrm{~mm}$ to $2500 \mathrm{~mm}$, but they prefer moist soil (Schonau 1984, Hengari 2007, Baltazar et al 2009, Goudzwaard 2011).

Gas exchange rates were measured on mature leaves (third and fourth leaves from the shoot top) using an open-type gas exchange system (LI-6400, LI-Cor, Lincoln, Nebraska, USA) in mid-August 2008. Measurements were carried out under a photosynthetic photon flux of $1500 \mu \mathrm{mol} \mathrm{m} \mathrm{m}^{-2}$, the light level corresponding to the light saturated photosynthetic rate for these plants in the growing environment. The leaf temperature was controlled at $25^{\circ} \mathrm{C} \pm 1^{\circ} \mathrm{C}$, and the leaf vapor pressure deficit (VPD) was maintained at $1.2 \pm 0.2 \mathrm{kPa}$. The photosynthetic WUE $\left[\mathrm{mmol} \mathrm{mol}{ }^{-1}\right]$ was calculated as $P_{\mathrm{N}}$ divided by $E$. The stomatal conductance in the measurements was regulated by maintaining the leaf temperature and vapour pressure deficit at values stated. It took $15-20 \mathrm{~min}$ for the stomata to equilibrate with the changed-condition after clipping the leaf to the chamber at every new measurement.

To obtain the response curve of net assimilation rate $\left(P_{N}\right)$ to intercellular $\mathrm{CO}_{2}$ concentration $\left(C_{\mathrm{i}}\right)$, i.e., the $P_{N} / C_{\mathrm{i}}$ curve, we established 12 values for the external $\mathrm{CO}_{2}$ concentration in the chamber and determined the corresponding values of $P_{N}$ (from 60 to 1,500 $\left.\mu \mathrm{mol} \mathrm{mol} \mathrm{m}^{-1}\right)$. The $P_{N} / C_{\mathrm{i}}$ curve was used to estimate the light-saturated net photosynthetic rate $\left(P_{\mathrm{Nmax}}\right)$, stomatal conductance $\left(g_{\mathrm{s}}\right)$ and leaf transpiration rate $(E)$ at 380 $\mu$ mol $\mathrm{mol}^{-1}\left(\mathrm{CO}_{2}\right)$, and the maximum rate of carboxylation $\left(V_{\mathrm{cmax}}\right)$ and maximum rate of electron transport $\left(J_{\max }\right)$ (Farquhar et al. 1980, Long and Bernacchi 2003). The Rubisco Michaelis constants for $\mathrm{CO}_{2}\left(K_{\mathrm{c}}\right)$ and $\mathrm{O}_{2}\left(K_{\mathrm{o}}\right)$ and the $\mathrm{CO}_{2}$ compensation point in the absence 
of dark respiration $\left(\Gamma^{*}\right)$ for the analysis of the $P_{N} / C_{\mathrm{i}}$ curve were obtained from Bernacchi $e t$ al. (2001). All gas-exchange parameters were expressed on the basis of the projected (onesided) leaf area covered.

Leaf Nitrogen Measurement: The leaves were excised from the plants in order to measure the leaf mass per area [LMA, $\mathrm{g}(\mathrm{DM}) \mathrm{m}^{-2}$ ], and to determine the $\mathrm{N}$ concentration per unit dry-mass $\left[N_{\text {mass }}, \mathrm{g} \mathrm{g}^{-1}\right.$ or $\left.\%(\mathrm{DM})\right]$ and per unit area $\left[N_{\text {area }}, \mathrm{g}(\mathrm{DM}) \mathrm{m}^{-2}\right]$. After the leaf area had been measured, the leaves were oven dried at $60^{\circ} \mathrm{C}$ for one week to determine their dry mass. The leaf $\mathrm{N}$ content was determined using a combustion method with a NC analyzer (NC-900, Sumica-Shimadzu, Kyoto, Japan). The PNUE $\left[\mu \mathrm{mol} \mathrm{mol}{ }^{-1} \mathrm{~s}^{-1}\right]$ was calculated by dividing $P_{\mathrm{N}}$ by the area-based leaf $\mathrm{N}$ content and molecular mass of nitrogen.

The estimation of $\mathbf{N}$ allocation to photosynthetic system: The nitrogen allocation to photosynthetic apparatus can be divided into three components: (1) Rubisco (N1), (2) bioenergetics or electron carriers except for photosystems, coupling factor and Calvin cycle enzymes except for Rubisco (N2), (3) light-harvesting complex and photosystems (N3). In this study we calculated only $\mathrm{N} 1$ and $\mathrm{N} 2$ to represent $\mathrm{N}$ allocation to the photosynthetic capacity (Westbeek et al. 1999). N1 was estimated from the following equation (Niinemets et al. 1999b; Tissue and Lewis 2010):

$$
\mathrm{N} 1=V_{\mathrm{cmax}} /\left(6.25 V_{\mathrm{cr}} \operatorname{LMA} N_{\mathrm{m}}\right),
$$

where $V_{\text {cr }}$ denotes the specific activity of Rubisco (the maximum rate of RuBP carboxylation per unit Rubisco protein) which is equal to $20.5 \mu \mathrm{mol}\left(\mathrm{CO}_{2}\right) \mathrm{g}(\text { Rubisco })^{-1} \mathrm{~s}^{-1}$ at $25^{\circ} \mathrm{C}$ for purified Rubisco enzyme from Spinacia oleracea (Jordan and Ogren 1984), and $N_{\mathrm{m}}$ is N per unit leaf mass, the factor of 6.25 [g Rubisco $\mathrm{g}^{-1}(\mathrm{~N})$ in Rubisco] would convert $\mathrm{N}$ content to 
protein content. The value of $\mathrm{N} 1$ from this calculation is underestimated because this method determines only the amount of activated Rubisco (Warren and Adams 2004).

The N2 was estimated according to the following equation (Kitaoka and Koike 2004; Takashima et al. 2004):

$$
\mathrm{N} 2=J_{\max } /\left(156 \times 9.53 \text { LMA } N_{\mathrm{m}}\right),
$$

whereas $\mathrm{N}$ in bioenergetics is assumed to be proportional to $J_{\max }$, the coefficient $156 \mathrm{mmol}$ $\mathrm{mol}^{-1} \mathrm{~s}^{-1}$ is the ratio of $J_{\max }$ to the cytochrome $f$ content (Niinemets and Tenhunen 1997), and the coefficient $9.53 \mathrm{~mol} \mathrm{mmol}^{-1}$ represents $\mathrm{N}$ in bioenergetics per unit cytochrome $f$ (Hikosaka and Terashima 1995).

Statistical Analysis: For each parameter measured, one-way analysis of variance (ANOVA) was used to test differences between the species. The net photosynthetic rate was compared between eucalypts and acacia using the two-tailed $t$-test. The test was performed using SPSS 16.0.2 (SPSS Inc., USA).

\section{Results}

LMA, leaf N, PNUE, and Photosynthetic Response: The LMA value was similar for the two acacia, and higher than that of the eucalypts (Fig 1). Among the eucalypts, the LMA was greater in E. camaldulensis than in the other species. For $N_{\text {area }}$ the tendency was similar, with larger values for acacias than eucalypts. In the acacias, $N_{\text {area }}$ was greater for A. auriculiformis than A. mangium, while E. camaldulensis had the largest $N_{\text {area }}$ of the eucalypts. The $N_{\text {mass }}$ did not differ significantly either within or between the genera. For PNUE the trend was opposite to that for LMA and $N_{\text {area. }}$ PNUE was lower for acacias than eucalypts, and of the eucalypts $E$. camaldulensis had the lowest PNUE (Fig. 1). 
A significant negative correlation between PNUE and LMA was observed for both genera, implying that the higher the LMA of the species, the lower the PNUE (Fig. 2A). The lower PNUE of acacias is presumably due to their higher $\mathrm{N}$ leaf content per unit area.

The $P_{\mathrm{N}}$ was significantly lower for acacias than for eucalypts (Table 1). Of the two acacias, $P_{\mathrm{N}}$ of $A$. auriculiformis was slightly higher than for A. mangium. Among the eucalypts, the highest value was for E. urophylla and lowest for E. grandis. Values of $P_{\mathrm{N}}$ did not differ statistically within genera.

Although $P_{\mathrm{N}}$ tended to increase with increasing leaf $\mathrm{N}$ in both genera, the correlation was not significant. However, the $P_{\mathrm{N}}$ of eucalypts were higher than that of the acacias at similar value of the leaf $N_{\text {area }}$ (Fig. 2B).

$V_{\text {cmax }}$ and $J_{\max }$ were not statistically different, either within or between genera (Table 1); however, values were lower for acacias than for eucalypts. Although not all differences were statistically significant, $A$. mangium had the lowest values of $P_{\mathrm{N}}, V_{\mathrm{cmax}}$, and $J_{\max }$, while E. camaldulensis had the highest. The $V_{\mathrm{cmax}}$ and $P_{\mathrm{N}}$ were significantly positively correlated. There was a positive correlation, though not statistically significant, between the $P_{\mathrm{N}}$ and $J_{\max }$, (Fig. 3).

In this study, the measurement of $\mathrm{N} 1$ and $\mathrm{N} 2$ represents $\mathrm{N}$ allocation to photosynthetic system. The $\mathrm{N}$ allocated to photosynthetic system was significantly greater in the eucalypts than the acacias (Fig. 4). Both N1 and N2 were the greatest for E. globulus, followed in order of E. grandis, E. urophylla, E. camaldulensis, A. mangium, and A. auriculiformis (Table 1).

We found that $P_{\mathrm{N}}, g_{\mathrm{s}}$, and $E$ were lower in acacias than in eucalypts (Table 1). Among the tested species, the lowest values of $g_{\mathrm{s}}$ and $E$ were for A. mangium, and the highest was for E. globulus.

WUE: On the genus basis, an independent two-tailed $t$-test indicated that the WUE of acacias was significantly higher than that of eucalypts. Conversely, there was little variation of WUE 
among the observed species (Table 1). Although there was no strong correlation, WUE increased as $N_{\text {area }}$ (Fig. 5) and LMA (Fig. 6) increased.

\section{Discussion}

Photosynthetic traits in relation with stomatal gas diffusion, nitrogen, and LMA: As the studied-species are all capable of growing in the subtropical environment (Thin et al. 1998, Bino 1998, Arnold and Luo 2002, Bauhus 2004, Yang et al. 2009), they were considered to be comparable as potential-species for afforestation and reforestation projects.

The lower $P_{\mathrm{N}}$ was apparently due to the significantly lower $g_{\mathrm{s}}$ for acacias than for eucalypts (Table 1 and Fig. 1). It is well known that $g_{s}$ is positively correlated with the rate of photosynthesis (e.g. Larcher 2003, Schulze et al. 2005). There was almost 50\% reduction in stomatal conductance of acacias than that of eucalypts (Table 1). Higher $N_{\text {area }}$ may be responsible for the lower $g_{\mathrm{s}}$ of acacias relative to eucalypts, leading to lower $\mathrm{CO}_{2}$ uptake through the stomata and hence a lower $P_{\mathrm{N}}$ (e.g. Lambers et al. 2008). Stomatal closure presumably played a large role in limiting the photosynthetic capacity of acacias relative to eucalypts, since there were no differences in $V_{\text {cmax }}$ and $J_{\max }$. Although $V_{\text {cmax }}$ and $J_{\max }$ were positively correlated with $P_{\mathrm{N}}$ (Fig. 3), they did not differ between acacias and eucalypts, nor within genus (Table 1). This implies that the photosynthetic capacity in chloroplast was not different among the tested species and was not the cause of the lower $P_{\mathrm{N}}$ of acacias than that of eucalypts.

The relation between $P_{\mathrm{N}}$ and $N_{\text {area }}$ was even corroborated when species were compared within the same genus. A. mangium of the acacias and E. camaldulensis of the eucalypts showed the highest $P_{\mathrm{N}}$ among their respective genus due to the highest $N_{\text {area. }}$ As acacias acquire $\mathrm{N}$ via symbiosis with $\mathrm{N}$-fixing microbes from the environment, they have greater $\mathrm{N}$ content in foliage. However, a comparison of the two genera gave an unexpected 
result; different from eucalypts, the high $N_{\text {area }}$ of acacias did not give rise to a high $P_{\mathrm{N}}$. Despite their higher leaf $\mathrm{N}$, acacias allocated a smaller portion of the leaf $\mathrm{N}$ to the photosynthetic system (defined by N1 and N2) than the eucalypts (Fig. 4). This may explain the lower $P_{\mathrm{N}}$ of the acacias than the eucalypts.

Leaf structure and $\mathrm{N}$ concentration affect photosynthetic capacity. A higher LMA usually implies greater investment in leaf dry-mass per unit leaf area, thicker leaf blade and denser tissue (Wright et al. 2004a, Reich et al. 1995). The increase in LMA roughly coincides with the decrease in photosynthetic capacity. High LMA corresponds to longer paths for diffusion from stomata to chloroplast, and greater internal shading of deeper chloroplasts, limiting the necessary $\mathrm{CO}_{2}$ supply and light irradiance for photosynthesis (Wright et al. 2004a, Terashima et al. 2001). Moreover, $\mathrm{N}$ is probably assigned less to photosynthetic machinery in acacias, because of competition with $\mathrm{N}$ allocation to nonphotosynthetic leaf components in high LMA species. These facts probably explain why acacias with higher LMA have lower $P_{\mathrm{N}}$ than eucalypts (Fig. 1).

The acacias have significantly higher LMA than the eucalypts, due presumably to the inherent difference in their typical leaf traits of xeromorphic adaptation. Whereas eucalypts bear true leaves, the foliage of the acacias is a modification of the leaf-petiole functioning like leaf blades, known as phyllodes (Niinemets 1999a, Leroy et al. 2009); these are thicker and stiffer than the true leaves of the eucalypts due to their denser mass per unit area. The higher LMA may account for a greater investment of resources in structural components of acacia foliages. Anatomically, phyllodes have thick cell wall and a two-layered palisade parenchyma at the abaxial and adaxial surfaces (Duarte and wolf 2005, Leroy et al. 2009), while the thickest sclerophyllous-true leaves of E. camaldulensis consist of a single layer of palisade parenchyma at the abaxial side (Souza et al. 1999). 
There was a significant positive correlation between $N_{\text {area }}$ and the LMA (data are not shown). Yet, the LMA difference between the two genera may not be due directly to the difference in leaf $N_{\text {area }}$, but more to the differing anatomical structure of the foliage, because, despite of the higher LMA, the $N_{\text {mass }}$ at the acacias foliage did not differ with that at the eucalypts (Fig. 1).

Photosynthetic nitrogen and water use efficiency: Lambers et al. (2008) stated that the PNUE at the growth irradiance would be greatest in leaves with lowest $\mathrm{N}$ concentration. For high PNUE, a species should allocate a reasonable amount of total leaf $\mathrm{N}$ to the photosynthetic system, and should deploy most $\mathrm{N}$ efficiently in photosynthesis. With higher $N_{\text {area }}$, acacias were found to have lower PNUE than the eucalypts. In this case, presumably a smaller proportion of leaf $\mathrm{N}$ allocated to photosynthetic capacity (N1 and N2) accounted for the lower PNUE of the acacias than eucalypts (Fig 4). Further, although it was not confirmed by the $N_{\text {mass }}$, the highest $N_{\text {area }}$ of E. camaldulensis caused this species to have the lowest PNUE among the eucalypts (Fig. 1).

PNUE is strongly correlated with LMA (Poorter and Evans 1998, Hikosaka 2004, Harrison et al. 2009). Acacias with higher LMA had lower PNUE than the eucalypts (Fig. $2 B$ ). This result confirms that plants with high LMA almost invariably have low PNUE (e.g. Poorter and Evans 1998, Ponds and Westbeek 2004). These high LMA species were less Nefficient due to, either they overinvest in photosynthetic $\mathrm{N}$ (Poorter and Evans 1998,Westbeek et al. 1999), or they invest $\mathrm{N}$ in other functions (e.g. the structural $\mathrm{N}$ of cell wall protein) more than in photosynthesis protein and machinery (Ellsworth et al. 2004, Hikosaka 2004, Takashima et al. 2004). Lower N allocation to photosynthetic system i.e. N1 and N2 (Fig. 4) would be partly responsible for the negative correlation between LMA and PNUE. 
Low PNUE is usually observed in stress-tolerant species (e.g. Hikosaka and Hirose 2000) and in late successional species (Ellsworth and Reich 1996). According to Yang et al. (2009), Acacia mangium and A. auriculiformis have high tolerance to bare soil. Their low PNUE may therefore be related to their high stress-tolerance traits.

There was little variation of photosynthetic WUE among the observed species. However, WUE of the acacias was significantly higher than that of the eucalypts. Eucalypts with low $N_{\text {area }}$ allocated a larger portion of $\mathrm{N}$ to photosynthetic system (Fig. 4) which would determine the $\mathrm{CO}_{2}$ drawdown inside the leaf, so that $g_{\mathrm{s}}$ increases to facilitate the higher $\mathrm{CO}_{2}$ uptake for photosynthetic capacity (Schulze et al. 1994, Farquhar et al. 2002). As $g_{\mathrm{s}}$ for the eucalypts increased, transpiration through stomata also increased, so that these plants had lower WUE than the acacias (Table 1).

There was a positive correlation between WUE and LMA (Fig. 6). Since we maintained the leaf temperature and VPD stable, the variation in $E$ was not affected by leaf temperature and VPD but was influenced more by diffusion resistance. A high LMA with thicker and more compact tissue could enhance water diffusion resistance (Givnish 1998), thus lower $g_{s}$ of acacias should be attributed to their high LMA, causing greater leaf resistance to the transpirational water diffusion (i.e. lower $E$ ).

There are strong correlations of LMA with both PNUE and WUE. Species with high LMA tend to have high WUE but lower PNUE (e.g. Poorter and Evans 1998, Mediavilla 2001, Lambers et al. 2008). The high LMA of phyllodes of acacias cause these plants to maintain higher WUE but consequently decline the PNUE (Fig. 2B and 6).

Consideration of acacia and eucalypt for afforestation: Acacias can be found in arid and semiarid environments, whereas eucalypts grow naturally in more favourable sites and therefore have a relatively higher growth rate. Eucalypts demand soil with moist and short water deficit conditions (e.g. Hengari 2007, Baltazar et al. 2009, Goudzwaard 2011). The 
ecophysiological characteristics determine how the photosynthetic rate of these genera develops. Acacias expend energy in fixing $\mathrm{N}$ and maintain a high LMA (Wright et al. 2004b, Tunstall 2005). They can adapt better to drought and aridity, and effectively prevent water loss (i.e. high WUE) due to the phyllode structure with high LMA (e.g. Hansen 1996, Eamus and Cole 1997, Sommerville et al. 2011), at the expense of lower PNUE and $P_{\mathrm{N}}$. The eucalypts used $\mathrm{N}$ more efficiently than the acacias so as to maintain a higher rate of $P_{\mathrm{N}}$, but they utilized water more generously in the photosynthetic process.

Despite of the advantages, acacias have high $\mathrm{N}$ in leaves, this tend to attract herbivore attack (Novriyanti et al. 2010), which should be anticipated in afforestation and reforestation projects. Further, there are deliberation to plant both acacia and eucalypts as complementary rather than as competitors (e.g. Forrester et al. 2006, Schiavo et al. 2009, Zahid et al. 2010) so as to recover degraded areas.

Conclusion: The variation in the LMA was due to the underlying difference in foliage anatomical structure and biomass density between acacias and eucalypts. This differing LMA entailed variation in PNUE and WUE within and among these two genera. Considering acacia and eucalypt as material for afforestation, they employ different strategies in utilizing $\mathrm{N}$ and water in their photosynthetic system. Under conditions of unlimited water and $\mathrm{N}$, the eucalypts surpassed the acacias with higher $P_{\mathrm{N}}$, as a result of higher PNUE, in the expense of photosynthetic WUE. However, acacias may benefit from their capability to acquire $\mathrm{N}$ from the air for their needs, which could improve the soil $\mathrm{N}$ status. The acacias also had higher WUE, which implies their moderate water usage in photosynthesis relative to eucalypts.

\section{References}

Alves, P.L.C.A., Magalhães, A.C.N., Barja, P.R: The phenomenon of photoinhibition of 
photosynthesis and its important in reforestation. - Bot. Rev. 68: 193-208, 2002.

Armstrong, W.P.: A large genus of trees \& shrubs. - Zoonooz 71: 23-81, 1998.

Arnold, R., Luo, J.: Cold tolerance plantation eucalypts for South Central China. - In: Wei, R.-P., Xu, D. (ed.): Eucalyptus plantation: research, management and development. - Proc. Inter. Symp., Guangzhou, China, September $1^{\text {st }}-6^{\text {th }}$ 2002. Pp. 90-101, Guangzhou, 2002.

Baltazar, E.M., Asis, L.E., Cambay, M.V. (ed.): Eucalyptus urophylla and Acacia mangium. - Research Information and Series on Ecosystem 21 (1), Laguna, 2009.

Barja, P.R., Mansanares, A.M., Silva, E.C., Magalhães, A.C.N., Alves, P.L.C.A.: Photosynthesis in eucalyptus studied by open photoacoustic technique: effect of irradiance and temperature. - Acoust. Phys. 47: 16-21, 2001.

Bauhus, J., van Winden, A.P., Nicotra, A.B.: Aboveground interactions and productivity in mixed-species plantation of Acacia mearnsii and Eucalyptus globulus. - Can. J. Forrest Res. 34: 686-694, 2004.

Bernachi, C.J., Singsaas, E.L., Pimentel, C., Portis, A.R., Long, S.P.: Improved temperature response functions for models of Rubisco-limited photosynthesis. - Plant Cell Environ. 24: 253-259, 2001.

Bino, B.: The performance of Acacia angustissima, A. auriculiformis, A. mangium as potential agroforestry tree species in the highland of Papua New Guinea. - In: Turnbull, J.W., Crompton, H.R., Pinyopusarerk, K. (ed.): Recent Developments in Acacia Planting. Proc. Int. Workshop, Hanoi, Vietnam, October $27^{\text {th }}-30^{\text {th }} 1997$. ACIAR, Canberra 1998.

Castellanos, A.E., Martinez, M.J., Llanoa, J.M., Halvorson, W.L., Espiricueta, M., Espejel, I.: Successional trends in Sonoran Desert abandoned agricultural fields in Northern Mexico. J. Arid Environ. 60: 437-455, 2005.

Cernusak, L.A., Aranda, J., Marshall, J.D., Winter, K.: Large variation in whole-plant wateruse efficiency among tropical tree species. - New Phytol. 173: 294-305, 2007. 
Duarte, M.R., Wolf, S.: Anatomical characters of the phyllodes and stem of Acacia podalyriifolia A. Cunn. Ex G. Don (Fabaceae). - Braz. J. Pharm. Sci. 15: 71-76, 2005.

Eamus, D., Cole, S.: Diurnal and seasonal comparison of assimilation, phyllode conductance and water potential of three acacia and Eucalyptus species in the wet-dry tropic of Australia. - Aust. J. Bot. 45: 275-290, 1997.

Ellsworth, D.S., P.B. Reich.: Photosynthesis and leaf nitrogen in five Amazonian tree species during early secondary succession. - Ecology 77: 581-594, 1996.

Ellsworth, D.S., Reich, P.B., Naumburg, E.S., Koch, G.W., Kubiske, M.E., Smith, S.D.: Photosynthesis, carboxylation, and leaf nitrogen of 16 species to elevated $\mathrm{pCO}_{2}$ across four free-air $\mathrm{CO}_{2}$ enrichment experiments in forest, grassland, and dessert. - Global Change Biol. 10: 2121-2138, 2004.

Farquhar, G.D., S. von Caemmerer, J.A. Berry.: A biochemical model of photosynthetic $\mathrm{CO}_{2}$ assimilation in leaves of $C_{3}$ species. - Planta 149: 78-90, 1980.

Farquhar, G.D., Buckley, T.N., Miller, J.M.: Optimal stomatal control in relation to leaf area and nitrogen content. - Silva Fenn. 36: 625-637, 2002.

Forrester, D.I., Bauhus, J., Cowie, A.L., Vanclay, J.K.: Mixed-species plantation of Eucalyptus with nitrogen fixing trees: a review. - Forest Ecol. Manag. 233: 211-230, 2006.

Francis, J.K.: Acacia mangium Willd. - In: US Depart. Agr. Forest Service: Tropical Seed Manual. Pp. 256-257. Washington 2002.

Funk, J.L., Vitousek, P.M.: Resource-use efficiency and plant invasion in low resource systems. - Nature 446: 1079-1081, 2007.

Garnier, E., Gobin, O., Poorter, H. Nitrogen productivity on photosynthetic nitrogen use efficiency and on nitrogen allocation within the plant. - Ann. Bot. 76: 667-672, 1995.

Givnish, T.J.: Adaption to sun and shade: a whole plant perspective. - Aust. J. Plant Physiol. 15: 63-92, 1998. 
Goudzwaard, L.: Eucalyptus globulus Labill., - Tree Fact Sheet, Forest Ecology and Forest Management Group, Wageningen Univ., Wageningen, 2011 [http://webdocs.dow.wur.nl/ internet/fem/uk/trees/eucglof.pdf].

Grassi, G., Meir, P., Cromer, R., Tompkins, D., Jarvis, P.G.: Photosynthetic parameter in seedlings of Eucalyptus grandis as affected by rate of nitrogen supply. - Plant Cell Environ. 25: 1677-1688, 2002.

Grattapaglia, D., Sederoff, R.: Genetic linkage maps of Eucalyptus grandis and Eucalyptus urophylla using a pseudo-test cross: mapping strategy and RAPD markers. - Genetics 137: 1121-1137, 1994.

Hai, P.H.: Genetic improvement of plantation-grown Acacia auriculiformis for sawn timber production. - Thesis. Swedish Univ Agr. Sci., Uppsala 2009.

Hansen, D.H.: Establishment and persistence characteristic in juvenile leave and phyllode of Acacia koa (leguminosae) in Hawaii. - Int. J. Plant Sci. 157: 123-128, 1996.

Harrison, M.T., Edwards, E.J., Farquhar, G.D., Nicotra, A.B., Evans, J.R.: Nitrogen in cell walls of sclerophyllous leaves accounts for little of the variation in photosynthetic nitrogen-use efficiency. - Plant Cell Environ. 32: 259-270, 2009.

Hengari, S.N.: The growth response of Eucalyptus grandis $\mathrm{x}$ Eucalyptus camaldulensis to salt stress, ectomycorrizhae and endomycorrhizahe double colonization. - Thesis. Univ. Stellenbosch, Stellenbosch, South Africa, 2007.

Heriansyah, I., Miyakuni, K., Kato, T., Kiyono, Y., Kanazawa, Y.: Growth characteristics and biomass accumulations of Acacia mangium under different management practices in Indonesia. - J. Trop. Forest Sci. 19: 226-235, 2007.

Hikosaka, K.: Interspecific difference in the photosynthesis-nitrogen relationship: patterns, physiological causes, and ecological importance. - J. Plant Res. 117: 481-494, 2004.

Hikosaka, K., Hirose, T.: Photosynthetic nitrogen-use efficiency in evergreen broad-leaved 
woody species coexisting in a warm-temperate forest. - Tree Physiol. 20: 1249-1254, 2000.

Hikosaka, K., Terashima, I.: A model of the acclimation of photosynthesis in the leaves of C3 plants to sun and shade with respect to nitrogen use. - Plant Cell Environ. 18: 605-618, 1995.

Huang, Z., Xu, Z., Blumfield, T.J., Bubb, K.: Effect of mulching on growth, foliar photosynthetic nitrogen and water use efficiency of hardwood plantation in subtropical Australia. - Forest. Ecol. Manag. 225: 3447-3454, 2008.

Jordan, D.B., W.L. Ogren.: The $\mathrm{CO}_{2} / \mathrm{O}_{2}$ specificity of ribulose 1,5-bisphosphate carboxylase/oxygenase. Dependence on ribulose bisphosphate concentration, $\mathrm{pH}$ and temperature. - Planta 161: 308-313, 1984.

Jøker, D. Seed leaflet: Acacia auriculiformis Cunn ex. Benth. - Danida Forest Seed Center, Humlebaek 2000.

Kitaoka, S., Koike, T.: Invasion of broad-leaf tree species into a larch plantation: seasonal light environment, photosynthesis and nitrogen allocation. - Physiol. Plant. 121:604-611, 2004.

Kruger, E.L., Volin, J.C.: Reexamining the empirical relation between plant growth and leaf photosynthesis. - Funct. Plant Biol. 33: 421-429, 2006.

Lambers, H., Chapin, F.S., III, Ponds, T.L.: Plant physiological ecology $2^{\text {nd }}$ Ed. - Springer Science+Bussiness Media, LLC, New York 2008.

Larcher, W.: Physiological plant ecology: ecophysiology and stress physiology of functional groups. $4^{\text {th }}$ Ed., Springer, Berlin 2003.

Lee, D.W., Oberbauer, S.F., Johnson, P., Krishnapilay, B., Mansor, M., Mohamad, H., Yap, S.K.: Effects of irradiance and spectral quality on leaf structure and function in seedlings of two Southeast Asian Hopea (Dipterocapaceae) species. - Am. J. Bot. 87: 447-455 2000. Leroy, C., Guéroult, M., Wahyuni, N.S., Escoute J., Céréghino R., Sabatier, S., Auclair, D.: 
Morphogenetic trends in the morphological, optical and biochemical features of phyllodes in Acacia mangium Willd (Mimosaceae). - Trees-Struct. Funct. 23: 37-49 2009.

Lewis, J.D., Phillips, N.G., Logan, B.A., Hricko, C.R., Tisue, D.T.: Leaf photosynthesis, respiration and stomatal conductance in six Eucalyptus species native to mesic and xeric environments growing in a common garden. - Tree Physiol. 31: 997-1006, 2011.

Long, S.P., Bernachi, C.J.: Gas exchange measurements, what can they tell us about the underlying limitations to photosynthesis? Procedures and sources of error. - J. Exp. Bot. 54: 2393-2401, 2003.

Mediavilla, S., Escudero, A., Heilmeier, H.: Internal leaf anatomy and photosynthetic resource-use efficiency: interspecific and intraspecific comparison. - Tree Physiol. 21: 251-259, 2001.

Niinemets, Ü., Components of leaf dry mass per area - thichness and density - alter leaf photosynthetic capacity in reverse directions in woody plants. - New Phytol. 144: 35-47, 1999.

Niinemets, Ü., Tenhunen, J.D.: A model separating leaf structural and physiological effects on carbon gain along light gradients for the shade-tolerant species Acer saccharum. - Plant Cell Environ. 20: 845-866, 1997.

Niinemets, Ü., Tenhunen, J.D., Canta, N.R., Chavis, M.M., Faria, T., Pereira J.S., Reynolds, J.F.: Interactive effects of nitrogen and phosphorus on the acclimation potential of foliage photosynthetic properties of cork oak, Quercus suber, to elevated atmospheric $\mathrm{CO}_{2}$ concentrations. - Global Change Biol. 5: 455-470, 1999.

Novriyanti, E., Aoyama, C., Watanabe, M., Takayoshi, K.: Plant defense characteristics and hypotheses in birch species. - Eurasian J. Forest Res. 13: 77-85, 2010.

Orwa, C., Mutua, A., Jamnadass, R., Anthony, S. Agroforestry database: a tree reference and selection guide version 4.0. - World Agroforestry Centre ICRAF, Nairobi, Kenya, 2009. 
(http://www.worldagroforestry.org/sites/treedbs/treedatabases.asp).

Pinyopusarerk, K., Doran, J.C., Williams, E.R., Wasuwanich, P.: Variation in growth of Eucalyptus camaldulensis provenances in Thailand. - Forest Ecol. Manag. 7: 63-73, 1996.

Ponds, T.L., Westbeek, M.H.M.: Analysis of differences in photosynthetic nitrogen use efficiency between four contrasting species. - Physiol. Plant 122: 68-78, 2004.

Poorter, H., Evans, J.R.: Photosynthetic nitrogen use efficiency of species that differ inherently in specific leaf area. - Oecologia 116: 26-37, 1998.

Prior, L.D., Bowman, D.M.J.S., Eamus, D.: Seasonal differences in leaf attributes in Australian tropical tree species: family and habitat comparisons. - Ecology 18: 707-718, 2004.

Quang, T.H., Kien, N.D., von Arnold, S., Jansson, G., Thinh, H.H., Clapham, D.: Relationship of wood composition to growth traits of selected open-polinated families of Eucalyptus urophylla from a progeny trial in Vietnam. - New Forest 39: 301-312, 2010.

Reich, P.B., Koike, T., Gower, T., Schoette, A.W.: Causes and consequences of variation in conifer leaf life-span. - In Smith W.K. and Hinckley, T.M. (ed.): Ecophysiology of Coniferous Forest. Pp. 225-254. Acad. Press, New York 1995.

Robinson, D.E., Wagner, R.G., Bell, F.W., Swanton, C.J.: Photosynthesis, nitrogen-use efficiency, and water-use efficiency of jack pine seedlings in competition with four boreal forest plant species. - Can. J. Forest Res. 31: 2014-2025, 2001.

Schiavo, J.A., Busato, J.G., Martins, M.A., Canellas, L.P.: Recovery of degraded areas revegetated with Acacia mangium and Eucalyptus with special references to organic matter humification. - Sci. Agric. 66: 353-360, 2009.

Schonau, A.P.G.: Silvicultural considerations for high productivity of Eucalyptus grandis. Forest Ecol. Manag. 9: 295-314, 1984.

Schulze, E.-D., Back, E., Müller-Hohenstein, K.: Plant Ecology. Springer, Berlin - 
Heidelberg 2005.

Schulze, E.D., Kelliher, F.M., Körner, C., Llyod, J., Leuning, R.: Relationships among maximum stomatal conductance, ecosystem surface conductance, carbon assimilation rate, and plant nitrogen nutrition: a global ecology scaling exercise. - Annu. Rev. Ecol. Evol. 25: 629-660, 1994.

Sommerville, K.E., Sack, L., Ball, M.C.: Hydraulic conductance of acacia phyllodes (foliage) is driven by primary nerve (vein) conductance and density. - Plant Cell Environ. 35: 158$168,2012$.

Souza, G.M., Conçalves, A.N., de Almeida M.: Water deficit in relation to leaf and stem anatomy of Eucalyptus camadulensis Dehn. shoot cultivated in vitro. - Sci. Agric. 56: 723-731, 1999.

Takahashi, N., Tahara, K., Utsugi, H., Kojima, T., Egashira, Y., Abe, Y., Saito, M., Yamada, K.: Water Use Efficiency of Eucalyptus camaldulensis growing in arid region I Western Australia. - J. Chem. Eng. Japan 36: 391-400, 2002.

Takashima, T., K. Hikosaka, T. Hirose.: Photosynthesis or persistence: nitrogen allocation in leaves of evergreen and deciduous Quercus species. - Plant Cell Environ. 27: 1047-1054, 2004.

Terashima, I., Miyazawa, S., Hanba, T.: Why sun leaves thicker than shade leaves? Consideration based on analysis of $\mathrm{CO}_{2}$ diffusion in the leaf. - J. Plant Res. 114: 93-105, 2001.

Thin, H.H., Kha, L.D., Searle, S.D., Tung, H.V.: Performance of Australian temperate acacias on subtropical highlands of Vietnam. - In: Turnbull, J.W., Crompton, H.R., Pinyopusarerk, K. (ed.): Recent Developments in Acacia Planting. Proc. Int. Workshop, Hanoi, Vietnam, October $27^{\text {th }}-30^{\text {th }}$ 1997. Pp. 51-59, ACIAR, Canberra 1998.

Tissue, D.T., Lewis J.D.: Photosynthetic responses of cottonwood seedlings grown in glacial 
through future atmospheric [CO2] vary with phosphorus supply. - Tree Physiol. 30: 13611372, 2010.

Turnbull, J.W., Martensz, P.N., Hall, N.: Notes on lesser known Australian trees and shrubs with potential for fuelwood and agroforestry. - In: Turnbull, J.W. (ed.): Multipurpose Australian Trees and Shrubs: Lesser Known Species for Fuelwood and Agroforestry. ACIAR Monograph. Pp. 81-90. Aust. Center Int. Agr. Res., Canberra 1986.

Tunstall, B.R.: Acacias - Eucalypts strategies for water and nutrients. - Environmental Research \& Information Consortium (ERIC) AAGT, Melbourne, 2005. (www.eric.com.au).

Warren, C.R., Adams, M.A.: Evergreen trees do not maximize instantaneous photosynthesis. - Trends Plant Sci. 9: 270-274, 2004.

Westbeek, M.H.M., Pons, T.L., Cambridge, M.L., Atkin, O.K.: Analysis of differences in photosynthetic nitrogen use efficiency of alpine and lowland Poa species. - Oecologia 120: 19-26, 1999.

Wright, I.J., Groom, P.K., Lamount, B.B., Poot, P., Prior, L.D., Reich, P.B., Schulze, E.-D., Veneklass, E.J., Westoby, M.: Leaf traits relationships in Australian plant species. - Funct. Plant Biol. 31: 551-558, 2004b.

Wright, I.J., Reich, P.B., Westoby, M., Ackerly, D.D., et al.: The world wide leaf economics spectrum. - Nature 428: 821-827, 2004a.

Yang, L., Liu, N., Ren, N., Wang, J.: Facilitation by two exotic acacia: Acacia auriculiformis and Acacia mangium as nurse plant in South China. - Forest Ecol. Manag. 257: 1786-1793, 2009.

Yu, H., Ong, B.L.: Effect of radiation quality on growth and photosynthesis of Acacia mangium seedlings. - Photosynthetica 41: 349-355, 2003. 
Zahid, D.M., Shah, F., Majeed, A.: Planting Eucalyptus camaldulensis in arid environment is it useful species under water deficit system? - Pak. J. Bot. 42: 1733-1744, 2010. 
Table 1. Leaf net photosynthetic rate $\left(P_{\mathrm{N}}\right)$, maximum rate of carboxylation $\left(V_{\text {cmax }}\right)$, maximum rate of electron transport $\left(J_{\max }\right)$, stomatal conductance $\left(g_{\mathrm{s}}\right)$, transpiration rate $(E)$, water use efficiency (WUE), and the photosynthetic capacity (N1 and N2) of the leaves of two acacias and four eucalypt seedlings. Data are mean values \pm SD ( $n=3$ ); values followed by the same letter do not differ significantly; $P<0.05$ (ANOVA and Tukey HSD test). Differences in the mean value of acacias and eucalypts were analyzed by the two-tailed $t$-test; ns - non significant differences, $*$ - significant differences $\left({ }^{* * *}-P<0.001{ }^{* *}-0.001<P<0.01\right)$.

\begin{tabular}{|c|c|c|c|c|c|c|c|c|c|}
\hline & \multicolumn{6}{|c|}{ Individual species } & \multicolumn{3}{|c|}{ Average } \\
\hline & A. auriculiformis & A. mangium & E. camaldulensis & E. globulus & E. grandis & E. urophylla & Acacia & Eucalypt & $t$-test \\
\hline$P_{\mathrm{N}}\left[\mu \mathrm{mol} \mathrm{m}^{-2} \mathrm{~s}^{-1}\right]$ & $15.3 \pm 3.3^{\mathrm{ab}}$ & $13.0 \pm 3.6^{\mathrm{a}}$ & $19.37 \pm 2.1^{\mathrm{b}}$ & $17.87 \pm 1.7^{\mathrm{ab}}$ & $17.59 \pm 0.9^{\mathrm{ab}}$ & $18.60 \pm 0.7^{\mathrm{ab}}$ & $14.1 \pm 3.3$ & $18.4 \pm 1.4$ & \\
\hline 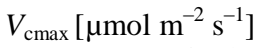 & $82.5 \pm 16.7^{\mathrm{a}}$ & $75.3 \pm 11.5^{\mathrm{a}}$ & $89.2 \pm 8.1^{\mathrm{a}}$ & $86.7 \pm 8.6^{\mathrm{a}}$ & $83.8 \pm 4.6^{\mathrm{a}}$ & $90.5 \pm 10.3^{\mathrm{a}}$ & $78.9 \pm 13.4$ & $87.5 \pm 7.1$ & ns \\
\hline$J_{\max }\left[\mu \mathrm{mol} \mathrm{m} \mathrm{m}^{-2}\right]$ & $133.7 \pm 14.3^{\mathrm{a}}$ & $126.7 \pm 24.2^{\mathrm{a}}$ & $150.2 \pm 19.6^{\mathrm{a}}$ & $134.6 \pm 6.5^{\mathrm{a}}$ & $130.4 \pm 16.0^{\mathrm{a}}$ & $134.9 \pm 14.0^{\mathrm{a}}$ & $130.2 \pm 18.2$ & $137.53 \pm 14.2$ & ns \\
\hline$g_{s}\left[\mathrm{~mol} \mathrm{~m}{ }^{-2} \mathrm{~s}^{-1}\right]$ & $0.29 \pm 0.06^{\mathrm{ab}}$ & $0.24 \pm 0.19^{\mathrm{a}}$ & $0.50 \pm 0.09^{\mathrm{ab}}$ & $0.56 \pm 0.14^{\mathrm{b}}$ & $0.48 \pm 0.19^{\mathrm{ab}}$ & $0.44 \pm 0.17^{\mathrm{ab}}$ & $0.26 \pm 0.13$ & $0.49 \pm 0.14$ & $* * *$ \\
\hline$E\left[\mathrm{mmol} \mathrm{m}^{-2} \mathrm{~s}^{-1}\right]$ & $3.76 \pm 1.18^{\mathrm{ab}}$ & $2.79 \pm 1.46^{\mathrm{a}}$ & $5.20 \pm 1.39^{\mathrm{b}}$ & $5.13 \pm 0.30^{\mathrm{b}}$ & $5.30 \pm 1.45^{\mathrm{b}}$ & $4.77 \pm 0.80^{\mathrm{ab}}$ & $3.28 \pm 1.30$ & $5.10 \pm 0.95$ & $* * *$ \\
\hline WUE $\left[\mathrm{mmol} \mathrm{mol}^{-1}\right]$ & $4.13 \pm 0.41^{\mathrm{ab}}$ & $5.03 \pm 1.10^{\mathrm{b}}$ & $3.85 \pm 0.78^{\mathrm{ab}}$ & $3.51 \pm 0.52^{\mathrm{a}}$ & $3.50 \pm 0.98^{\mathrm{a}}$ & $3.96 \pm 0.55^{\mathrm{ab}}$ & $4.59 \pm 0.89$ & $3.71 \pm 0.66$ & $* *$ \\
\hline $\mathrm{N} 1[\%]$ & $11.45 \pm 3.1^{\mathrm{a}}$ & $17.07 \pm 4.36^{\mathrm{a}}$ & $26.76 \pm 0.26^{\mathrm{a}}$ & $75.53 \pm 4.61^{\mathrm{c}}$ & $60.49 \pm 16.79^{\mathrm{bc}}$ & $56.39 \pm 10.41^{\mathrm{b}}$ & $14.26 \pm 4.57$ & $54.04 \pm 19.54$ & $* * *$ \\
\hline $\mathrm{N} 2[\%]$ & $1.59 \pm 0.27^{\mathrm{a}}$ & $2.50 \pm 0.82^{\mathrm{ab}}$ & $3.89 \pm 0.44^{b}$ & $9.73 \pm 0.44^{\mathrm{d}}$ & $7.89 \pm 0.98^{\mathrm{cd}}$ & $7.45 \pm 2.48^{\mathrm{c}}$ & $2.04 \pm 0.74$ & $7.24 \pm 2.50$ & $* * *$ \\
\hline
\end{tabular}




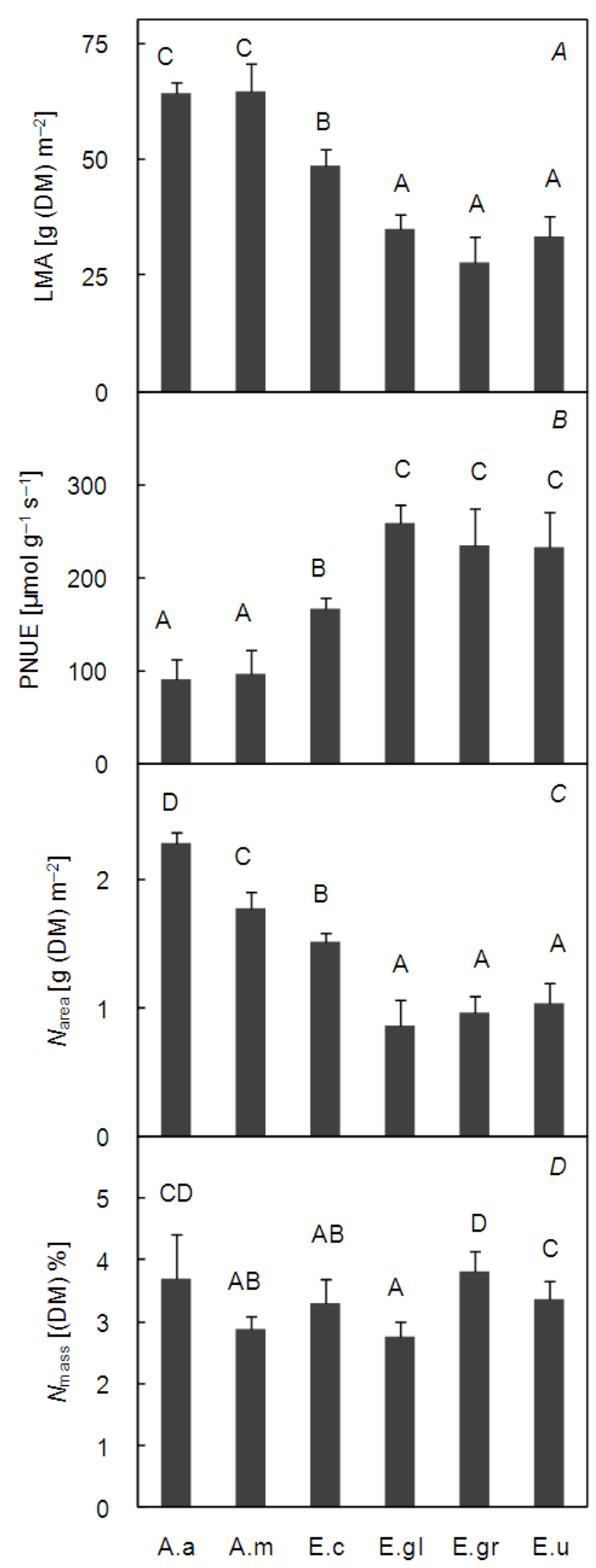

Figure 1. Leaf mass per area (LMA), photosynthetic nitrogen use efficency (PNUE), nitrogen content per leaf area $\left(N_{\text {area }}\right)$ and nitrogen content per leaf mass $\left(N_{\text {mass }}\right)$ of two acacias (A.a $=A$. auriculiformis; A.m = A. mangium) and four eucalypts $($ E.c $=$ E. camaldulensis; E.gl $=$ E. globulus; E.gr = E. grandis; E.u = E. urophylla $)$. Data are average values $\pm \mathrm{SD}(\mathrm{n}=3)$. Bars that have the same letter do not differ significantly according to the Tukey HSD test at P < 0.05 . 


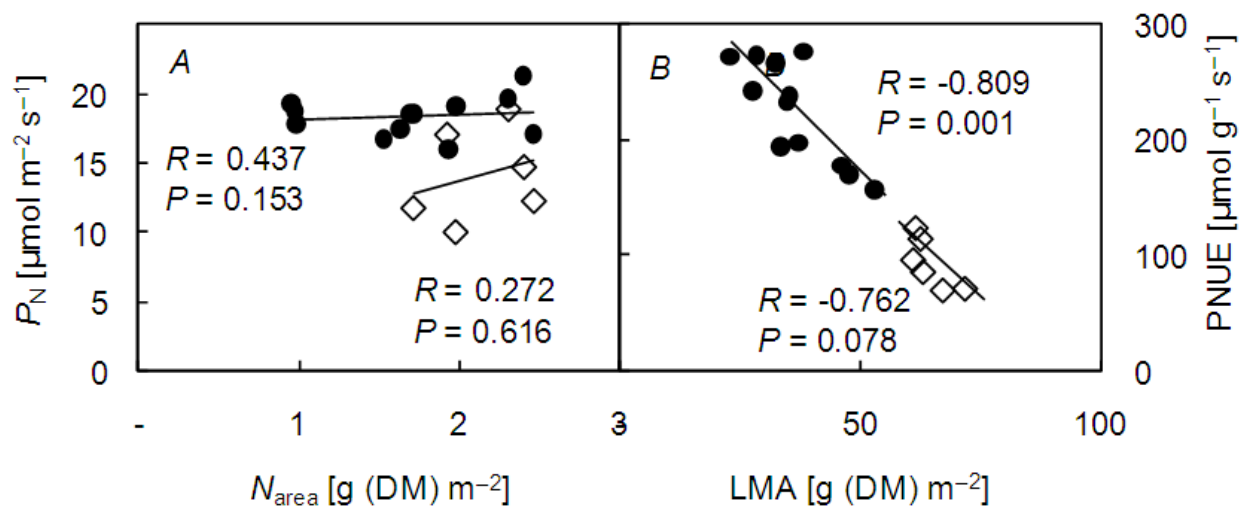

Figure 2. Relations between leaf nitrogen content per leaf area $\left(N_{\text {area }}\right)$ and light saturated photosynthetic rate $\left(P_{\mathrm{N}}\right)(A)$, and the relation between leaf mass per area (LMA) and photosynthetic nitrogen use efficency (PNUE) (B).( $\square$ : acacias, $\bullet$ : eucalypts)

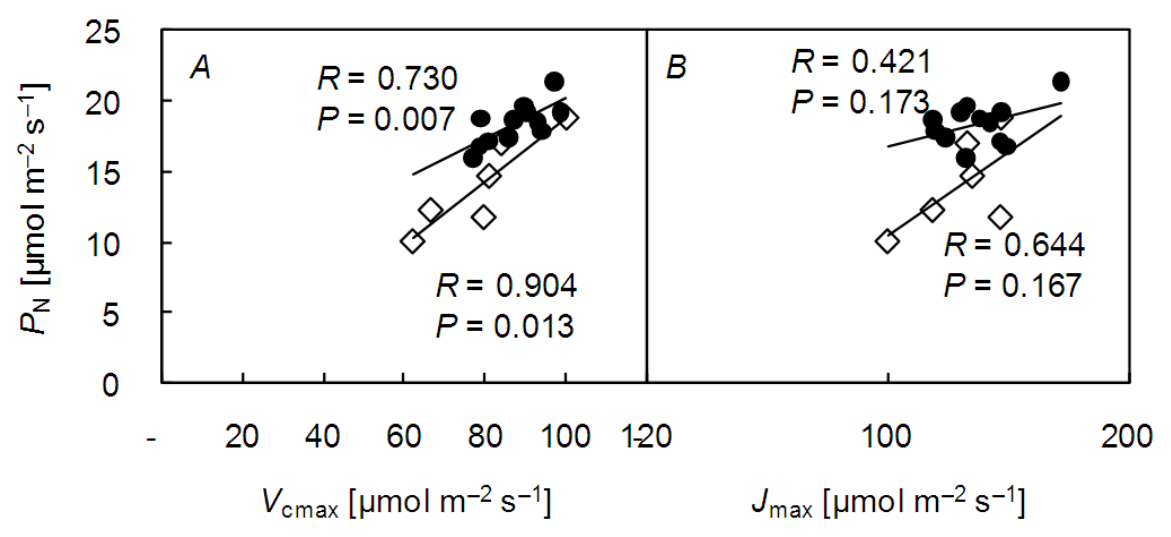

Figure 3. Variation of the maximum rate of carboxylation $\left(V_{\mathrm{cmax}}\right)(A)$ and maximum rate of electron transport $\left(J_{\max }\right)(B)$ with net photosynthetic rate $\left(P_{\mathrm{N}}\right)(\square$ : acacias, $\bullet$ : eucalypts) 


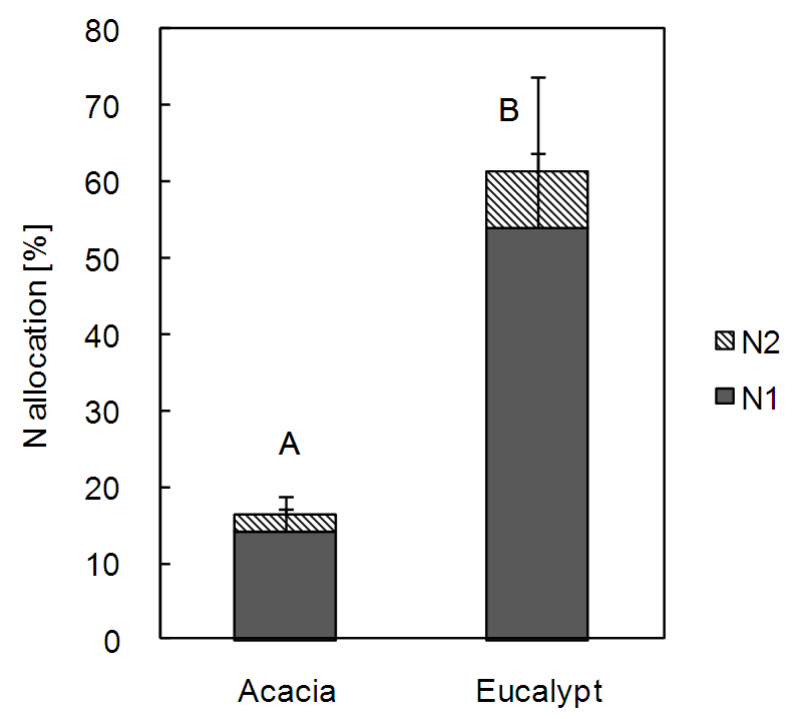

Figure 4. Nitrogen allocation in the leaves of tested species. N1, nitrogen allocated to Rubisco; N2, nitrogen allocated to electron carriers except for photosystems, coupling factor and Calvin cycle enzymes apart from Rubisco; Values with different letters attached differ significantly for the sum of $\mathrm{N} 1$ and $\mathrm{N} 2$, with $P<0.05$.

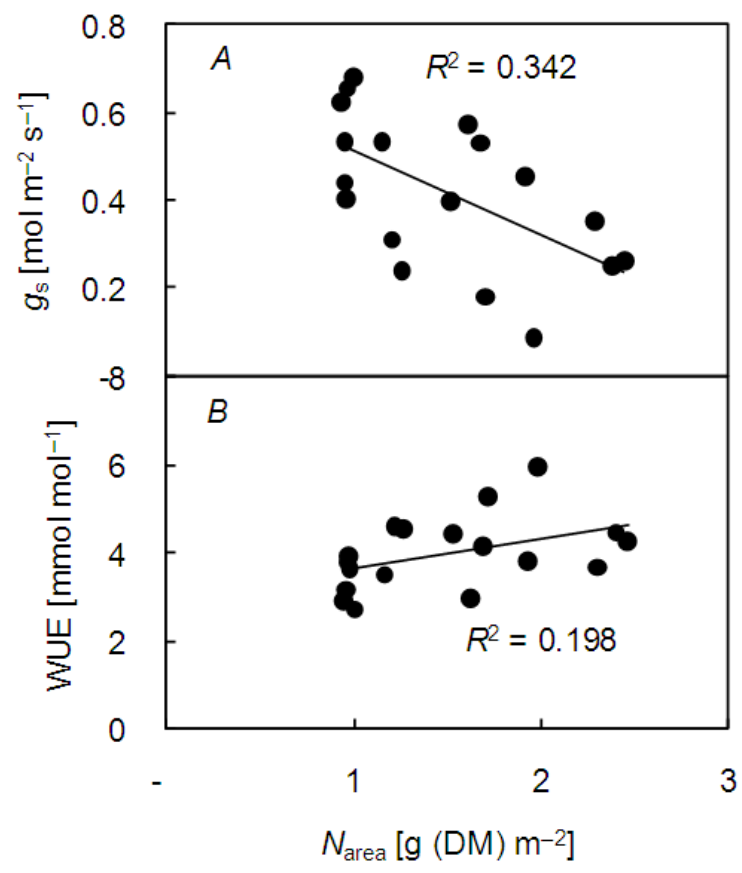

Figure 5. Variation of $N_{\text {area }}$ with stomatal conductance $\left(g_{\mathrm{s}}\right)(A)$ and photosynthetic water use efficiency (WUE) (B). 


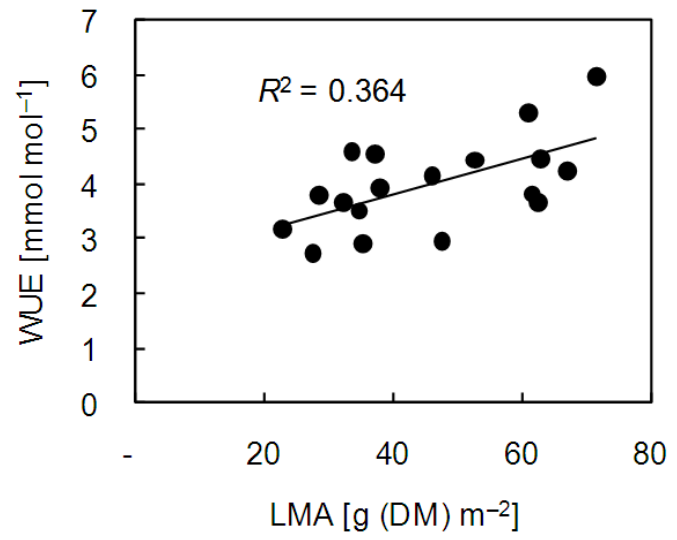

Figure 6 . The relation between LMA and WUE. 